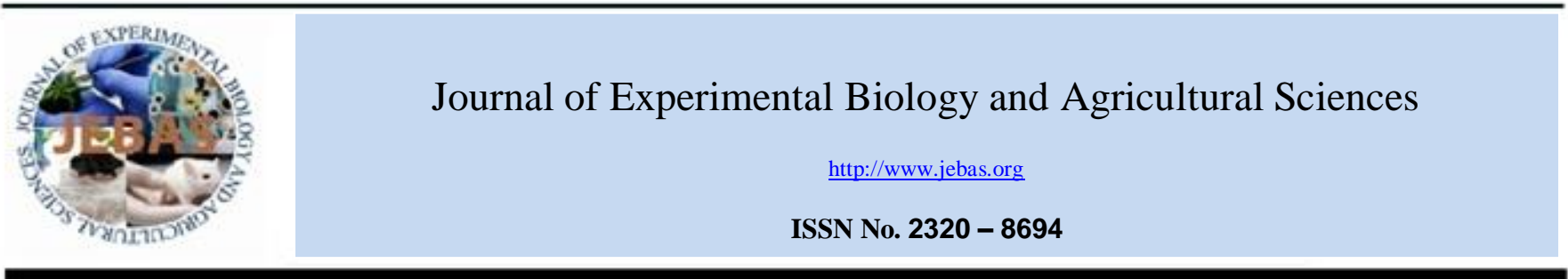

\title{
INFLUENCE OF ENVIRONMENTAL FACTORS ON THE POPULATION DYNAMICS OF CHILLI THRIPS, Scirtothrips dorsalis (HOOD) AND APHID, Aphis gossypii (GLOVER)
}

\author{
Deepak Kumar, Kamal Ravi Sharma, S.V.S. Raju* \\ Department of Entomology \& Agriculture Zoology, Institute of Agricultural Science, Banaras Hindu University, Varanasi- 221005
}

Received - April 22, 2019; Revision - May 27, 2019; Accepted - June 07, 2019

Available Online - June 10, 2019

DOI: http://dx.doi.org/10.18006/2019.7(3).289.294

\section{KEYWORDS \\ Chilli \\ Environmental effects \\ Population fluctuation \\ Chilli thrips \\ Aphid}

* Corresponding author

E-mail: svsraju_bhu@yahoo.com (S.V.S. Raju)

Peer review under responsibility of Journal of Experimental Biology and Agricultural Sciences.

Production and Hosting by Horizon Publisher India [HPI] (http://www.horizonpublisherindia.in/).

All rights reserved.

\begin{abstract}
Insect pests continue to pose a major threat for achieving higher production of chilli crop. The experiment was conducted to study population dynamics of chilli thrips and aphids at Varanasi on 100 $\mathrm{m}^{2}$ unsprayed field during 2016-17. The chilli thrips and aphid population were counted from ten randomly selected chilli plants and the abiotic factors like temperature, relative Humidity $(\mathrm{RH})$, rainfall were also recorded. Result of the study revealed that chilli thrips population first appeared during the third week of September and reached its peak during the third week of October. However, the incidence of the aphid population commenced from the fourth week of September and attained peak population levels during the fourth week of October. Further the correlation analysis of abiotic factors with chilli thrips population showed that the positive correlation with maximum temperature whereas, a negative correlation with relative humidity during morning, relative humidity during evening, minimum temperature and rainfall were also observed. While the aphid population showed positive correlation with maximum temperature. However, negative correlations were observed with relative humidity during morning, relative humidity during evening, rainfall and minimum temperature. These results of present study help in the development of the forecasting model and timely preparedness to manage pest problems and prevent crop losses.
\end{abstract}

All the article published by Journal of Experimental Biology and Agricultural Sciences is licensed under a Creative Commons Attribution-NonCommercial 4.0 International License Based on a work at www.jebas.org.

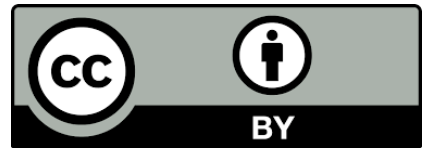




\section{Introduction}

Chilli (Capsicum annuum L.) which is an important vegetable cash crop in India and is grown for the demand of its pungent fruits, both green and ripe (latter dried form) to added pungency to the food. As a condiment, it has become indispensable in every Indian home. It is also used medicinally, and in chutneys and pickles (Das, 2013). The world consumption of chillies and paprika is going up due to the increasing popularity of ethnic foods. India is the largest producer as well as consumer of chilli in the world with the production of 3634 (in 000 MT) but its production pattern is highly erratic (Anonymous, 2017). Although the crop has excellent export potential in addition to national demand, it contributes to its low productivity through multiple limiting factors. The sustainability in chilli production is threatened by many biotic stresses such as several insect pests and diseases (Hanumanthappa et al., 2018). Insect pests continue to pose a major threat for achieving higher production of chilli crops and about 57 species of pests were recorded by Reddy \& Puttaswamy (1984) which attacked on chilli crop and causes yield losses to range between 50 to 90 per cent (Rajput et al., 2017).

The results of the survey conducted by Asian Vegetable Research and Development Centre (AVRDC) indicated that the major sucking insect pests that attack chilli are thrips (Scirtothrips dorsalis Hood) and aphids (Myzus persicae Sulzer, Aphis gossypii Glover) in Asia (Anonymous, 1987). Chilli thrips, S. Dorsalis is regarded to be one of the most damaging pests and may lose 30 to $50 \%$ of the plant under serious infestation (Bhede et al., 2008). Thrips can cause damage to chilli directly by feeding on leaves, fruits or flowers. Feeding injury from thrips on leaves may affect leaf size, affect carbon allocation in the plant (Welter et al., 1990; Shipp et al., 1998) and reduce photosynthetic capacity (Tommasini \& Maini, 1995). Thrips also cause indirect damage by transmitting the number of plant virus genera (Jones, 2005). The aphid is also one of the most important constraints in chilli production. Aphid became the most destructive insect pests of chilli in India and did huge economic damage. One recent study reported that severely infested chilli plant almost failed to produce any fruits or produced a bare minimum number of deformed fruits (Shi et al., 2011). Under favorable conditions, aphid reproduces at a faster rate and may cause damage to $15-30 \%$ of total chilli production (Das, 2013). Climatic factors such as temperature, relative humidity and rainfall are also known to have a significant influence on insect population fluctuation (Sharma et al., 2018). The basic information on the relative occurrence and population dynamics are necessary before deciding the strategy for management of any insect pest (Manjunatha et al., 2001; Meena et al., 2013). Knowledge of the seasonal abundance and population build up trend is essential to ensure timely preparedness to manage pest problems and prevent crop losses and it also to help in the development of the forecasting model which is a useful tool to predict likely incidence of the insect pests on the crop. In this regard, the present investigation was carried out to estimate population dynamics of chilli thrips and aphids on chilli in relation to weather parameters.

\section{Materials and Methods}

\subsection{Experimental site}

The experiment was conducted during the year 2016-17 at the Vegetable Research Farm, B.H.U., Varanasi, India. Varanasi lies between $24^{\circ} 56^{\prime} \mathrm{N}$ to $25^{\circ} 35^{\prime} \mathrm{N}$ Latitude and $82^{\circ} 14^{\prime} \mathrm{E}$ to $83^{\circ} 24^{\prime}$ E Longitude and the elevation is $82 \mathrm{~m}$ above the mean sea level, almost in the centre of Indo-Gangetic belt and it possesses subtropical climate. Pure seeds of the test variety, Bhagyalakshmi (G4) were raised in the nursery on the experimental site on $3^{\text {rd }}$ August 2016. Other care was taken as per the recommendations to maintain the nursery under unsprayed conditions.

\subsection{Field preparation and transplanting}

Summer ploughing was given to the main field with the aim of exposing eggs and another stage of harmful insect pests and under-ground reproductive parts of weeds. A bulk plot of $100 \mathrm{~m}^{2}$ was raised to study the population dynamics of chilli thrips and aphid. Thirty days old seedlings were transplanted in the main field on $2^{\text {nd }}$ September 2016 with a plant spacing of $60 \times 45 \mathrm{~cm}$. All the recommended agronomic practices like weed control, fertilizer application and irrigations were followed except for chemical treatment of the experimental plot.

\subsection{Pest sampling}

The observations of pest population were recorded in these unprotected plot at 7 days interval (Standard weeks) from 7 days after transplanting (DAT) up to crop harvesting. The population of chilli thrips and aphids were counted on fully opened leaves from ten randomly selected plants and three leaves (One from the top, middle and lower canopy) from each plant were taken for recording the pest population. The population of both nymphs and adults were counted early in the morning before $8 \mathrm{AM}$ when the pests were not much active.

\subsection{Meteorological data}

Weather data were recorded simultaneously from the metrological observatory available at agricultural research farm, institute of agricultural Sciences, BHU, Varanasi and correlated with the occurrence of the pest population. A simple correlation coefficient method was adopted to work out the relationship between the occurrence of the pest and the weather parameters. 


\subsection{Statistical analysis}

Weekly data of pest population was correlated with the prevailing climatic factors such as maximum temperature, minimum temperature, morning and evening relative humidity and rainfall was analyzed by calculating respective " $\mathrm{r}$ " (correlation coefficient) with the help of SPSS (Statistical Package for Social Sciences) software.

\section{Results}

\subsection{Chilli thrips}

The data present in Table 1 revealed that the chilli thrips population was initially observed on $38^{\text {th }}$ Standard Week (SW) i.e., at 12 days after transplantation with a mean population of 0.28 thrips per leaf and the corresponding average maximum and minimum temperature prevailed during the initial infestation were $31.2^{\circ} \mathrm{C}$ and $25.6^{\circ} \mathrm{C}$, respectively and average morning and evening relative humidity was $92 \%$ and $82 \%$, respectively. The population of thrips increased from $39^{\text {th }} \mathrm{SW}$ and reached a peak level (4.47 thrips/leaf) on $43^{\text {th }} \mathrm{SW}$ (Figure 1). The pest population had a gradual decline after $43^{\text {rd }} \mathrm{SW}$ and reached its minimum population (0.21 thrips / leaf) during $1^{\text {st }} \mathrm{SW}$, corresponding to a peak and minimum temperature of $20.10{ }^{\circ} \mathrm{C}$ and $11.60{ }^{\circ} \mathrm{C}$ respectively, while the relative moisture of morning and evening was $95 \%$ and $76 \%$ respectively. Table 2 showed that the correlation between chilli thrips population and the major weather parameters. The findings disclosed that the population of chilli thrips showed a

Table 1 Seasonal incidence of chilli thrips and aphids on chilli during 2016-17

\begin{tabular}{|c|c|c|c|c|c|c|c|c|}
\hline \multirow{2}{*}{$\begin{array}{l}\text { Standard } \\
\text { week }\end{array}$} & \multirow{2}{*}{ Month-date } & \multirow{2}{*}{$\begin{array}{c}\text { Rainfall } \\
\mathrm{mm}\end{array}$} & \multicolumn{2}{|c|}{ Temperature ${ }^{\circ} \mathrm{C}$} & \multicolumn{2}{|c|}{ Relative humidity $\%$} & \multirow{2}{*}{$\begin{array}{l}\text { Mean no. of } \\
\text { thrips/ leaf }\end{array}$} & \multirow{2}{*}{$\begin{array}{c}\text { Mean no. of } \\
\text { aphid/leaf }\end{array}$} \\
\hline & & & Max. & Min. & Morn. & Even. & & \\
\hline 36 & Sep 02-08 & 31.1 & 31.6 & 26.2 & 90 & 80 & 0 & 0 \\
\hline 37 & $09-15$ & 2.6 & 31.4 & 26.4 & 91 & 80 & 0 & 0 \\
\hline 38 & $16-22$ & 64.8 & 31.2 & 25.6 & 92 & 82 & 0.28 & 0 \\
\hline 39 & $23-29$ & 115.8 & 28.6 & 24.0 & 95 & 88 & 0.21 & 0.38 \\
\hline 40 & $30-06$ & 2.6 & 32.4 & 26.3 & 88 & 74 & 1.09 & 0.54 \\
\hline 41 & Oct $07-13$ & 1.5 & 32.0 & 23.4 & 87 & 61 & 2.28 & 2.48 \\
\hline 42 & $14-20$ & 0.0 & 32.4 & 18.4 & 74 & 43 & 3.17 & 3.25 \\
\hline 43 & $21-27$ & 0.0 & 32.4 & 17.9 & 74 & 43 & 4.47 & 4.65 \\
\hline 44 & $28-03$ & 0.0 & 31.4 & 16.6 & 77 & 43 & 3.89 & 6.87 \\
\hline 45 & Nov $04-10$ & 0.0 & 29.2 & 15.3 & 80 & 45 & 3.06 & 5.14 \\
\hline 46 & $11-17$ & 0.0 & 29.0 & 13.8 & 77 & 42 & 3.25 & 4.81 \\
\hline 47 & $18-24$ & 0.0 & 27.3 & 11.7 & 72 & 42 & 2.87 & 4.32 \\
\hline 48 & $25-01$ & 0.0 & 25.4 & 13.2 & 79 & 56 & 2.54 & 3.56 \\
\hline 49 & Dec 02-08 & 0.0 & 20.3 & 16.3 & 94 & 78 & 0.95 & 2.45 \\
\hline 50 & $09-15$ & 0.0 & 20.2 & 10.0 & 94 & 73 & 0.48 & 2.01 \\
\hline 51 & $16-22$ & 0.0 & 23.3 & 9.8 & 89 & 50 & 0.54 & 1.67 \\
\hline 52 & $23-31$ & 0.0 & 20.5 & 10.9 & 94 & 69 & 0.34 & 0.84 \\
\hline 1 & Jan $1-7$ & 0.0 & 20.1 & 11.6 & 95 & 76 & 0.21 & 0.69 \\
\hline 2 & $8-14$ & 0.0 & 20.7 & 8.2 & 91 & 44 & 0.00 & 0.48 \\
\hline 3 & $15-21$ & 0.0 & 23.0 & 8.8 & 90 & 49 & 0.00 & 0.31 \\
\hline
\end{tabular}

Max.- Maximum, Min.- Minimum, Morn.- Morning, Even.- Evening

Table 2 Correlation Coefficient (r) of chilli thrips and aphids on chilli with prevailing weather parameters during 2016-17

\begin{tabular}{|ccccc|c|}
\hline Parameters & $\begin{array}{c}\text { Maximum } \\
\text { Temperature }\end{array}$ & Minimum temperature & $\begin{array}{c}\text { Morning relative } \\
\text { humidity }\end{array}$ & $\begin{array}{c}\text { Evening relative } \\
\text { humidity }\end{array}$ & $-0.693 * *$ \\
\hline Chilli thrips & $0.484 *$ & -0.042 & $-0.912 * *$ & -0.326 & $-0.703 * *$ \\
\hline Aphids & 0.255 & -0.243 & $-0.817 * *$ & -0.377 \\
\hline
\end{tabular}

*Correlation is significant at $\mathrm{P} \leq 0.05 ; \quad * *$ Correlation is significant at $\mathrm{P} \leq 0.01$ 


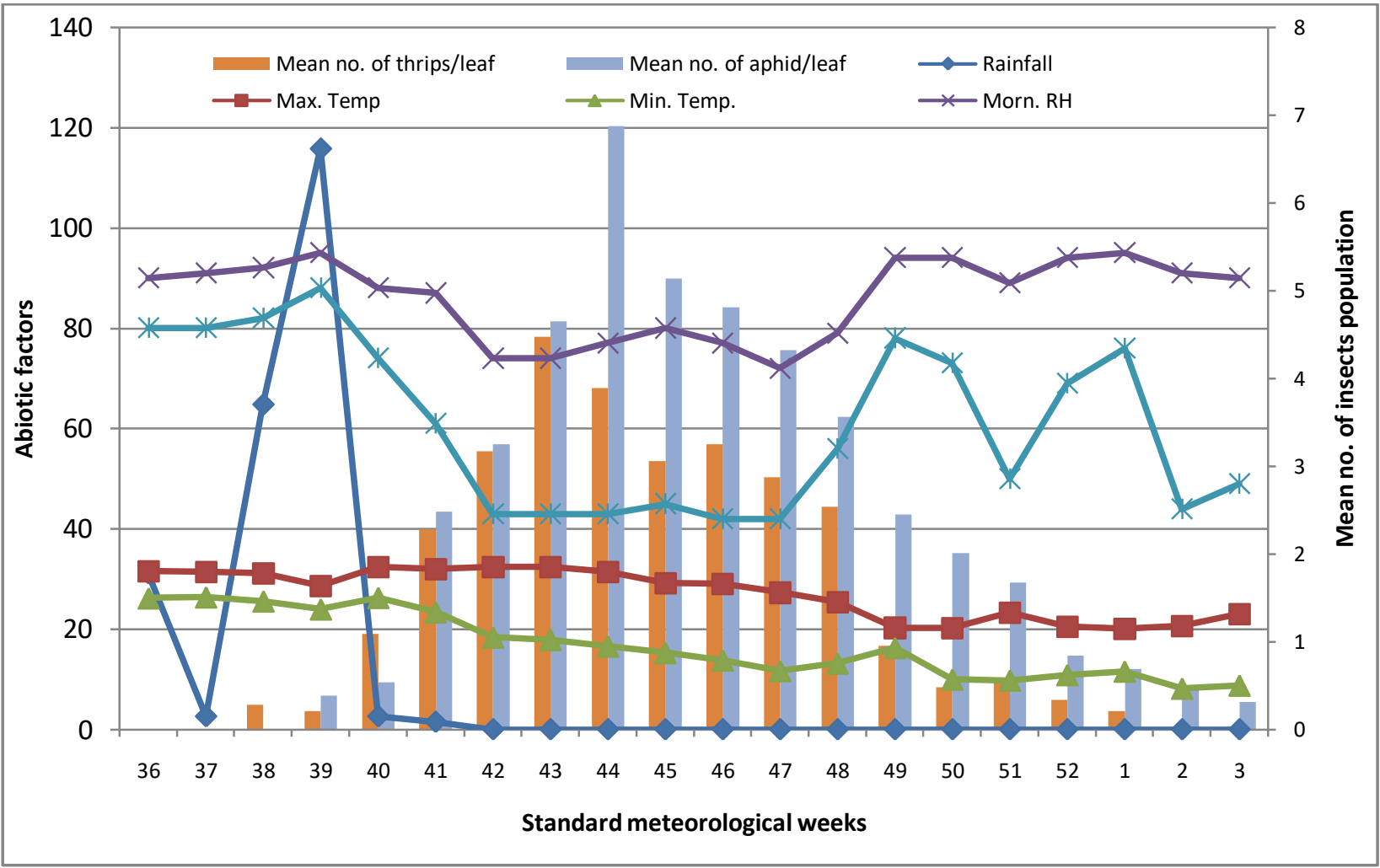

Figure 1 Influence of abiotic factors on the population chilli thrips and aphid

positive significant correlation with maximum temperature $(r=0.484)$. Again, there was a negative significant correlation of pest count with morning relative humidity $(r=-0.912)$ and evening relative humidity $(\mathrm{r}=-0.693)$ and a negative nonsignificant correlation with minimum temperature $(r=-0.042)$ and rainfall $(r=-0.326)$.

\subsection{Aphids}

The data presented in Table 1 revealed that the incidence of aphid was initially observed on $39^{\text {th }} \mathrm{SW}$ i.e., at $18^{\text {th }}$ day after transplantation with a mean population of 0.38 aphids per leaf and corresponding average maximum and minimum temperature prevailed during the initial infestation were $28.6^{\circ} \mathrm{C}$ and $24.0^{\circ} \mathrm{C}$, respectively and morning relative humidity and evening relative humidity was $95 \%$ and $88 \%$, respectively. The population of aphid had increased from $39^{\text {th }} \mathrm{SW}$ with 0.38 aphids/leaf and attainted its peak level (6.87 aphids/leaf) on $44^{\text {th }} \mathrm{SW}$ (Figure 1). After $44^{\text {th }} \mathrm{SW}$, the pest population gradually declined and reached its minimum of 0.31 aphids/leaf during $3^{\text {rd }} \mathrm{SW}$ and the corresponding peak and minimum temperatures were $23.0{ }^{\circ} \mathrm{C}$ and $8.8{ }^{\circ} \mathrm{C}$ respectively, while the relative humidity in the morning and evening was $90 \%$ and $49 \%$ respectively
The correlation between population of chilli thrips and abiotic factors shown in Table 2. The results indicated that the correlation between the aphid population and maximum temperature $(\mathrm{r}=0.255)$ was positive but non-significant while, negative nonsignificant correlation was observed with minimum temperature (-0.243). Further, a negative significant correlation was reported between the pest population and morning relative humidity $(\mathrm{r}=-0.817)$ and evening relative humidity $(\mathrm{r}=-0.703)$ and $\mathrm{a}$ negative non-significant correlation with rainfall $(-0.377)$ were also notice during the experimental period.

\section{Discussion and Conclusion}

The results of the present investigation showed that the incidence of thrips population was commenced during the $3^{\text {rd }}$ week of September and the pest population reached its peak level during the $4^{\text {th }}$ week of October. Earlier, Patel et al. (2009) and Barot et al. (2012) reported similar observation that the incidence of $S$. dorsalis on chilli crop commenced from the first week of September and continue up to the harvest of the crop being peak activity was recorded in November. Further, Meena et al. (2013) reported that peak population of the thrips occurred during the $41^{\text {th }}$ standard week (October) and Chandra \& Rana (2014) also 
observed that the population of $S$. dorsalis on chilli crop attained its peak at the beginning of autumn season (first half of October 2013). The correlation between population of chilli thrips and abiotic factors shown in Table 2. The chilli thrips populations during the season revealed a significant positive correlation with maximum temperature while, non- significant negative correlation with minimum temperature and rainfall. However, a significant negative correlation observed with morning and evening relative humidity. The results are in close accordance with Pathipati et al. (2014) who also observed that the thrips population had a negative correlation with minimum temperature, morning and evening relative humidity, rainfall and positive correlation with maximum temperature. Further, Asma \& Hanumantharaya (2015) also recorded a highly significant and positive correlation of thrips with maximum temperature. Lingeri et al. (1998) also reported that thrips population increased during the dry period with lower minimum temperature, while Kumar et al. (2006) and Meena et al. (2013) reported that the thrips showed a negative correlation with relative humidity.

Whereas, the incidence of the aphid population was first observed during the $4^{\text {th }}$ week of September and reached to a peak during the $44^{\text {th }}$ standard week (October) thereafter pest population declined. These observations are in close accordance with the results obtained by Roopa \& Kumar (2014) that the infestation of aphid started during the third week of September. The incidence was observed throughout the cropping season and peak incidence was attained during the third and fourth week of October. These results are also in close confirmation with Bharadiya \& Patel (2005) who reported that the peak activity of aphid, A. gossypii, during third week of November. Meena et al. (2013) observed that the aphids appeared little late during the year in chilli crop. The correlation analysis of pest populations was positive nonsignificant with maximum temperature. However, a negative and non- significant correlation was observed with minimum temperature and rainfall whereas, a negative and highly significant correlation was found with morning relative humidity and evening relative humidity. These results are in close association with the findings of Yadav et al. (2014) who reported a negative correlation between the temperature, humidity and rainfall with aphid population. Further, Debaraj \& Singh (2004) reported the negative correlation between temperature and aphid infestation. Roopa \& Kumar (2014) also revealed that the aphid population exhibited a negative correlation with maximum temperature, minimum temperature and sunshine hours.

From the above findings it can be concluded that the peak period of chilli thrips population was recorded in the third week of October $\left(43^{\text {rd }}\right.$ standard week) and the aphid population was recorded highest in the fourth week of October $\left(44^{\text {th }}\right.$ standard week). The correlation ananlysis with abiotic factors revealed that temperature showed a positive impact on the population of chilli thrips and aphid, while relative humidity and rainfall showed a negative impact on the population of chilli thrips and aphid. These findings could help in the development of the forecasting model which will be a useful tool to predict likely incidence and intensity of the insect pests on the crop to ensure timely preparedness to manage pest problems and prevent crop losses.

\section{Acknowledgement}

The authors are thankful to Government of Uttar Pradesh for providing scholarship and Institute of Agricultural Sciences, BHU, Varanasi, for providing facilities to conduct the experiments.

\section{Conflict of Interest}

Authors would hereby like to declare that there is no conflict of interests that could possibly arise.

\section{References}

Anonymous (1987) Progress Report for 1987, Asian Vegetable Research and Development Centre, Pp. 77-79.

Anonymous (2017) Agricultural statistics at a glance. Government of India, Ministry of Agriculture, Department of Agriculture and Cooperation, Directorate of Economics and Statistics.

Asma A, Hanumantharaya L (2015) Population dynamics of major insect and mite pests of chilli. Journal of Experimental Zoology India 18: 173-176.

Barot BV, Patel JJ, Shaikh AA (2012) Population dynamics of chilli thrips, Scirtothrips dorsalis Hood in relation to weather parameters. AGRES - An International e-Journal 1: 480-485.

Bharadiya AM, Patel BR (2005) Succession of insect pests of brinjal in north Gujarat. Pest Management and Economic Zoology 13: $159-161$.

Bhede BV, Suryawanshi DS, More DG (2008) Population dynamics and bio-efficacy of newer insecticide against chilli thrips, Scirtothrips dorsalis (Hood). Indian Journal of Entomology 70: 223-226.

Chandra M, Rana KS (2014) Seasonal Population Fluctuation of Thrips tabaci and Scirtothrips dorsalis (Thysanoptera: Thripidae) in Western Uttar Pradesh. Bulletin of Environment, Pharmacology and Life Sciences 3: 135-140.

Das G (2013) Efficacy of imidacloprid, a nicotinoid group of insecticide against the infestation of chilli aphid, Myzus persicae 
(Hemiptera: Aphididae). International Journal of Biology and Biological Sciences 2: 154-159.

Debaraj Y, Singh TK (2004) Population dynamics of cabbage aphid Brevicoryne brassicae (Linn.) in relation to abiotic and biotic factores at different altitudes of Manipur. Indian Journal of Entomology 66: 172-175.

Hanumanthappa PV, Chinnaswamy N , Annabathula MN, Reddy RS, Ramachandrappa NN (2018) Morphometric and molecular diversity among the isolates of colletotrichum species causing anthracnose disease of chilli. Journal of Experimental Biology and Agricultural Sciences 6: $124-130$

Jones DR (2005) Plant viruses transmitted by thrips. European Journal of Plant Pathology 113: 119-157.

Kumar MR., Reddy KL, Lakshmi V, Reddy DR, Gour TB (2006) Survey of thrips infesting roses and its relation with weather parameters. Indian Journal of Entomology 68: 197-202.

Lingeri MS, Awaknavar JS, Lingappa S, Kulkarni KA (1998) Seasonal occurrence of chilli mites (Polyphagotarsonemus latus (Banks) and thrips (Scirtothrips dorsalis Hood). Karnataka Journal Agriculture Science 11: 380-385.

Manjunatha M, Hanchinal SG, Reddy GVP (2001) Survey of yellow mite and thrips on chilli in North Karnataka. Insect Environment 6: 178.

Meena RS, Ameta OP, Meena BL (2013) Population dynamics of sucking pests and their correlation with weather parameters in chilli, Capsicum annum L. crop. The Bioscan 8: 177-180.

Patel BH, Koshiya DJ, Korat DM (2009) Population dynamics of chillithrips, Scirtothripsdorsalis Hood in relation to weather parameters. Karnataka Journal of Agricultural Sciences 22: 108-110.

Pathipati VL, Vijayalakshmi T, Naidu LN (2014) Seasonal incidence of major insect pests of chilli in relation to weather parameters in Andhra Pradesh. Pest Management in Horticultural Ecosystems 20: 36-40.

Rajput VS, Prajapati B.G, Pareek A, Patel PS (2017) Studies on
Population Dynamics of Major Insect Pests Infesting Chilli (Capsicum annum L.). International Journal of Pure Applied. Biosciences 5: 1465-1470.

Reddy DNR, Puttaswamy (1984a) Pest infesting chilli (Capsicum annuит L.) in the transplanted crop. Mysore Journal of Agriculture Science 19: 236- 237

Roopa M, Kumar CTA (2014) Seasonal incidence of pests of capsicum in Bangalore conditions of Karnataka, India. Global Journal of Biology, Agriculture and Health Sciences 3: 203-207.

Sharma KR, Raju SVS, Roshan DR, Jaiswal DK (2018) Effect of abiotic factors on yellow stem borer, Scirpophaga incertulas (walker) and rice leaf folder, Cnaphalocrocis medinalis (guenee) population. Journal of Experimental Zoology India 21: 233-236.

Shi X, Jiang L, Wang H, Qiao K, Wang D, Wang K (2011) Toxicities and sublethal effects of seven neonicotinoid insecticides on survival, growth and reproduction of imidaclopridresistant cotton aphid, Aphis gossypii. Pest Management Sciences 67: 1528-1533.

Shipp J, Hao X, Papadopoulos A, Binns M (1998) Impact of western flower thrips (Thysanoptera: Thripidae) on growth, photosynthesis and productivity of green house sweet pepper. Scientia Horticultura 78:87-102

Tommasini M, Maini S (1995) Frankliniella occidentalis and other thrips harmful to vegetable and ornamental crops in Europe. In: Loomans AJM, van Lenteren JC, Tommasini MG, Maini S, Ruidavets J (eds) Biological control of thrips pests, vol. 95, Wageningen University Papers, Wageningen, Pp. 1-42

Welter SC, Rosenheim JA, Johnson MW, Mau RFL, Gusukumaminuto LR (1990) Effects of thrips-palmi and western flower thrips (Thysanoptera, Thripidae) on the yield,growth, and carbon allocation pattern in cucumbers. Journal of Economic Entomology 83:2092-2101

Yadav AK, Acharya VS, Kashyap P, Meena VS, Singh SP (2014) Population dynamics of major sucking pests on chilli and its relationship with weather factors. Annals of Horticulture 7: 103-108. 